\title{
Aantekeninge/Notes
}

\section{Social security 'benefits' and the collateral source rule - an analysis of the three Coughlan decisions}

\section{Introduction}

The law of damages abounds with cases dealing with the collateral source rule. This rule is applicable to instances where the victim of a damagecausing event, despite suing the wrongdoer or his or her insurer for damages, receives a benefit from a third party (Mukheibir 'Road Accident Fund $v$ Timis - child support grants is not res inter alios acta' 2011 SALJ 246; see in general Potgieter, Steynberg \& Floyd Visser \& Potgieter's Law of Damages (2012) 229-273). However, despite the various case law and commentary in literature on the subject, this concept remains unburdened by clarity. This is particularly true as far as the interpretation and intersection between the application of the rule and social security benefits.

The first noteworthy decision in considering this interplay is Makhuvela $v$ Road Accident Fund (2010 1 SA 29 (GSJ)). The court had to consider the deductibility or otherwise of a foster care grant from an amount claimed for loss of support. Similarly, the court in Road Accident Fund v Timis ([2010] ZASCA 30; (26 March 2010) dealt with the deductibility of a child support grant from an amount claimed for loss of support.

Most recently, and important for this discussion, the question of the deductibility of foster care grants from an amount claimed for loss of support again received judicial attention in Coughlan $v$ Road Accident Fund. It will be shown that the outcomes of the three decisions, the High Court (977/08 WCC; 6 June 2013 (hereafter Coughlan High Court decision)), the Supreme Court of Appeal (2014 6 SA 376 (SCA) (hereafter Coughlan SCA decision)) and the Constitutional Court (2015 4 SA 1 (CC) (hereafter Coughlan CC decision)) are in principle fundamentally different. The only corresponding feature of the three cases is the clear illustration of the trite fact that the collateral source rule evolves on a casuistic basis.

This discussion is limited to social security grants received as a 'benefit' consequent to a damage-causing event and its relevance to the collateral source rule. Social security refers to the protection that the state provides for its citizens through public measures against economic and social distress (Steynberg \& Millard 'Distinguishing between private law

How to cite: Monyamane 'Social security 'benefits' and the collateral source rule - an analysis of the three 
and social-security law in deducting social grants from claim for loss of support' 2011 PER 2011 (14) 4260 at 267).

An interrogation of the three decisions will turn on the following key issues: the application of the collateral source rule; the benefit received and its source; the death-of-a-breadwinner requirement in claims for loss of support; and the viability of social grants as a general res inter alios acta.

\section{The Facts}

Mr Coughlan, in his capacity as curator ad litem for three minor children, lodged a claim against the Road Accident Fund in the Western Cape High Court in Cape Town (Coughlan v Road Accident Fund 977/08 (WCC)) for damages for loss of support as a result of the death of the children's mother in a motor vehicle accident. Consequent upon the accident and subsequent death of the deceased, the children's grandparents successfully approached the Children's Court to be appointed as foster parents to their grandchildren. Resulting from such appointment, the grandparents received a foster care grant in terms of section 8 of the Social Assistance Act (13 of 2004). The merits were conceded, and the respondent agreed to compensate the applicant in his representative capacity for $100 \%$ of the proven damage suffered as a result of the deceased's death. At the time of the hearing in the court of first instance, the amount received by the grandparents as a foster care grant was R146 790 whilst the amount agreed to be paid for loss of support was R 112 942. The issue before the court was whether the amount received as foster care grant should be deducted from the amount agreed for loss of support to the children or whether the foster care payments are to be considered res inter alios acta and therefore not deductible.

This discussion considers, in some detail, the decisions of the High Court, the Supreme Court of Appeal and the Constitutional Court in this regard.

\section{High Court}

Mr Coughlan relied on Makhuvela in contending that the foster care grant was paid out to the foster parents to enable them to comply with their obligations to the children. On this premise, it was submitted that the children had no claim to the money which therefore ought to be treated as res inter alios acta in regard to their claim for loss of support (par 12). However, the defendant leaned on the decision of the Supreme Court of Appeal in Timis and the interpretation of section 1(1) and (2) of the Assessment of Damages Act (9 of 1969) in arguing that the foster care grant is a benefit in terms of law and must therefore be deducted from an amount payable for loss of support (parr 13-19).

In agreeing with the judgment of Malan J in Makhuvela, the High Court, per Henney J, accepted that the death of the children's mother did not cause the grandparents to take care of the children but rather that her 
death only formalised the process of foster care (par 30). In essence, the High Court concluded that the foster care grant paid to the foster parents was res inter alios acta and could therefore not be deducted from the damages awarded.

The RAF appealed against that finding to the Supreme Court of Appeal.

\section{Supreme Court of Appeal}

The RAF contended that the High Court incorrectly relied on Makhuvela and urged the Supreme Court of Appeal to follow its own judgment in Timis (par 8). In this court, Lewis JA speaking for a unanimous court, held that, in principle, there was no difference between grants paid out in terms of section 6 (child support grant) and section 8 (foster care grant) of the Social Assistance Act. Thus, the court found that the foster care grant paid out to the grandparents served the same purpose as a claim for loss of support (par 21), providing the children with the financial support lost as a result of the death of their mother. In essence, the foster care grant was found to be a compensating advantage and therefore deductible. However, to further heighten the casuistry of the rule, the court went on to state that its finding 'does not mean that there is any general principle precluding an award of damages for loss of support where dependants have had the benefit of social support grants' (par 22).

As shall be demonstrated below, the difficulty in grappling with the question of deductibility of benefits is a real one. Therefore, legal certainty and development of this area of the law of damages could better be achieved by authoritative pronouncements of a general nature. The above quote is a clear example of an undesirable commitment to casuistry that continues to plague the collateral source rule.

The curator appealed against the Supreme Court of Appeal's finding to the Constitutional Court.

\section{Constitutional Court}

In a unanimous judgment delivered by Tshiqi AJ, the Constitutional Court upheld the appeal (2015 4 SA 1 (CC)). In deciding the question of law before it, the court addressed four compelling issues namely, the state's constitutional obligation to children in terms of sections 27 and 28 of the Constitution (of the Republic of South Africa, 1996 (hereafter the Constitution)); the nature and purpose of the foster child grant vis-a-vis awards for loss of support; the effect of Makhuvela; and, whether there is any causal link between a foster child grant and compensation for loss of support.

The court considered the state's obligations to the children in terms of the Constitution and section 156(1)(e) of the Children's Act (38 of 2008) and found that there is no justifiable reason to treat children in foster care differently to children in youth-care centres as far as compensation for loss of support is concerned. Notwithstanding this, the court noted the 
incompatibility of a foster child grant with a claim for loss of support, stating that:

an award for damages for loss of support is no substitute for foster parenting and there is no basis to deprive a child compensation for loss of support because they are in foster care (par 44).

The court further agreed with the decision in Makhuvela and conceded that a foster child grant is payable to the foster parent to discharge his or her responsibility to the child, while the award for loss of support is payable to the child to make good the loss of the monetary contribution suffered as a result of the death of a breadwinner (parr 45-46). In essence, according to the court, there is no basis to deduct the one from the other. In the final analysis, the court concluded that the nature and purpose of a social grant is different from compensation for loss of support and not predicated on the death of the parent (par 51).

\section{The Collateral Source Rule}

It is trite that a damage-causing event does not always result in only negative losses but may, in some instances, have positive benefits for the plaintiff. The inclusion or otherwise of the positive benefits of the damage-causing event has not always lent itself to a simple answer. This unresolved position owes much of its under- development to two conflicting general principles of the law of damages. On the one hand, the law does not allow for double compensation as a result of a single cause of action. On the other hand, it is stated that the wrongdoer or his or her insurer should not escape liability on account of some fortuitous event such as the generosity of a third party (Zysset and Others $v$ Santam Ltd 19961 SA 273 (CPD) 279B-C; Potgieter, Steynberg \& Floyd 233).

Mukheibir notes that there is no generally acceptable single test to determine whether or not a benefit ought to be deducted (Mukheibir 'Comparing the casuistry of compensating advantages and collateral sources' 2002 Obiter 330). This problem was further described as a question of demarcation in Standard General Insurance Co Ltd $v$ Dugmore (1997 1 SA 33 (A) 41 D-E), in other words, the question of whether or not to deduct, depends on the claim and the court's interpretation of the collateral source rule. Ultimately, the demarcation of benefits is determined by policy considerations of fairness (Dugmore supra at 42B). However, this is no easy task and this was patently acknowledged in a separate opinion of Marais JA in Dugmore when he captured the difficulty of this balance by stating that the:

dilemmas arise when one attempts to respect well-established principles (each of which has its own particular justification and reason for existence), but finds that in respecting one, one is spurning another, and that one's best efforts to reconcile them come to nought (Dugmore supra at 47D-E).

Notwithstanding the appreciation of this difficulty and the absence of satisfactory answers to the question of deductibility of benefits, it has long been established that there are exceptions to the rule against double 
compensation. For example, benefits received by the plaintiff under ordinary contracts of insurance for which the plaintiff has paid premiums; and money and other benefits received by the plaintiff as solatium or from the generosity of third parties motivated by sympathy are collateral benefits in any action for damages. It is apparent from the listed and generally accepted exclusions that the established exceptions of res inter alios acta do not address the absence of general principles to the question of deductibility or otherwise but rather considers a predetermined conclusion to exclude them from quantification (Monyamane The nature, assessment and quantification of medical expenses as a head of delictual damage(s) (LLM dissertation UNISA 2014) 60).

However, despite the inherent dangers of casuistry and the conflict of general principles of the law of damages as highlighted, Potgieter, Steynberg \& Floyd (supra at 233) submit that the application of the collateral source rule is flexible and must be considered in view of the interests of the plaintiff, the defendant, the source of the benefit, the community and other interested third parties. This echoes the view held in Zysset that the inquiry to determine the deductibility of benefits must necessarily include considerations of public policy, reasonableness and justice (Zysset supra at 279A).

\section{The Benefit Received and its Source}

Not much thought has been devoted to the essence and meaning of the benefit received except in instances where it satisfies the fairness requirement necessary to categorise a benefit as res inter alios acta. A number of cases dealing with various benefits have come before courts. Among them are Indrani and Another $v$ African Guarantee and Indemnity (1968 4 SA 606 (D)); Dippenaar v Shield Insurance Co Ltd (1979 2 SA 904 (A)); and Mutual and Federal Insurance Co Ltd $v$ Swanepoel (1988 2 SA 1 (A)). These cases considered the deductibility of pension funds based on a variety of sources. In Santam Versekeringsmaatskappy Bpk $v$ Byleveldt (1973 2 SA 146 (A)), the court grappled with the deductibility of wages that the employer continued to pay to an employee, despite incapacity. Erasmus and Ferreira \& Ackermann and Others $v$ Francis (2010 2 SA 228 (SCA)) dealt with whether pension benefits paid to a claimant was deductible in calculating damages paid to her as a result of a law firm's negligence.

The absence of clear guidelines as to the relevance of the essence of a benefit for purposes of the collateral source rule manifested itself in the decision of the Constitutional Court in Coughlan. The rationale, as adopted by the court, has the implied conclusion that a foster care grant is not per se a benefit. This is evidenced by the view of the court that foster care grants are unrelated to damages for loss of support and that the grants arise out of a constitutional obligation to care for children in need (par 51). Of course, this largely stems from the fact that the Constitutional Court found that the payment of a foster care grant is not 
generally predicated on the death of the breadwinner (par 51). Granted that there may be some merit to the argument that there is no nexus between foster care grants and loss of support, the court overstated the difference between the two in order to justify a statutory (constitutional) rights-based conclusion. It is not a hypothesis to state that the children of the deceased were only placed under their grandparents' foster care after the death of their mother. It is conceded that the court was correct in holding that foster parenting turns on the needs of the children to be cared for (par 37). However, the naked facts before the court pointed to the reality that this need was only satisfied after the death of the children's mother. Therefore, the question of deductibility as entertained by even the Constitutional Court itself must have led the court to the correct conclusion and acknowledgement that a foster care grant was indeed a benefit received only after the deceased's death.

This conclusion would, in n way, have suggested that the foster care grant is inevitably a compensating advantage. It is prudent, at this stage, to note that the correct application of the collateral source rule is limited to instances where the plaintiff receives a benefit directly and not where a third party receives the benefit for the benefit of the plaintiff. For this reason, the present author is inclined to agree with the High Court's judgment in its application of the conventional norms of the collateral source rule (Coughlan High Court decision supra).

As far as the source of the benefit is concerned, it is doubtful whether the source of the positive benefit is an altogether irrelevant factor (Potgieter, Steynberg \& Floyd 271). After all, this forms the essence of the established exception to the rule against double compensation. In determining whether public policy, reasonableness and justice warrant the inclusion of the benefit in damages, it is fitting that regard must be had to the actual benefit as well as its source. Although the source of the positive benefit may not satisfactorily address the question of deductibility on its own, it is submitted that it will address the question of purpose fairly well. Thus, in Coughlan, it may be that public policy, reasonableness and justice required the state to fulfil its obligations to the children in terms of sections 27 and 28 of the Constitution. For this reason, it is submitted that the identity of the source from which a positive benefit arises in no way hinders the process of determination but, if correctly considered in context, would make the process much easier. The Constitutional Court favoured an approach that emphasises constitutional rights and obligations over and above a consideration of the conventional delictual essence of the collateral source rule.

The Constitutional Court, in developing the common law, as it has done on a number of occasions, must promote the spirit, purport and objects of the Bill of Rights (s 39(2) of the Constitution). Be that as it may, the development of any law must also be practical. It stands to reason that, after the Constitutional Court's decision, the collateral source rule in general remained in exactly the same position in law as it had been before the matter reached the court. The one exception, however, is that 
the Constitutional Court's decision resolved the superfluous difference between Timis and Makhuvela. In effect, there is certainty regarding the deductibility or otherwise of social grants from amounts payable as damages. Thus, what is clear at this point is that both foster care and child support grants are to be accepted as general exclusions when determining the deductibility of benefits from claims for loss of support. In fact, in view of the elaborated exposition of the nature of foster care grants in the case, it is not even clear whether the court considered these grants to be benefits at all.

\section{The Death of a Breadwinner Requirement in Claims for Loss of Support}

Despite the fact that the Coughlan matter turns on the question of whether or not the foster child grant is deductible from a damages award, sight should not be lost of the main claim of the applicant. Essentially, the applicant was claiming for loss of support on behalf of the minor children as a result of the death of their mother. According to Corbett $\mathrm{J}$ in Evins $v$ Shield Insurance Co Ltd (19802 SA 814 (A) 839A), the general purport of a claim for loss of support is that the claimant is injured by the death of a breadwinner. Therefore, it follows, and this is in part supported by Steynberg \& Millard (2011 PER 273-274), that to satisfy an award of damages in this respect a link must first be established between the death of the breadwinner and loss of support as well as the death of the breadwinner and the subsequent receipt of the social grant in cases similar to the current one.

In the High Court, Henney J (Coughlan High Court decision supra at par 28), on the evidence, accepted that the children were in need of care before the death of their mother and that her death only served to formalise their subsequent placement in the foster care of their grandparents. This acknowledgement in no way swayed the court to conclude that the foster child grant was deductible. The Supreme Court of Appeal, however, was not inclined to accept the findings of the High Court. It found no evidence to support the conclusion that death only formalised the process of foster care and the subsequent receipt of foster child grants (Coughlan SCA decision supra at par 18). Although it is common cause that the two courts came to conflicting decisions on both fact and principle, it has to be emphasised that they both considered the legal issue by applying the conventional - though admittedly unsatisfactory - understanding of the collateral source rule. Both courts considered the cause of action, being the death of the breadwinner, and the deductibility or otherwise of the benefit which was the subject of litigation. This is the conventional way of addressing the collateral source rule.

It may well be that the need to appoint a foster parent is not predicated on the death of a breadwinner, as the Constitutional Court found (Coughlan CC decision supra at par 51). However, it is submitted that the court's line of reasoning was somewhat divorced from the facts of the 
case. The incompatible nature of the foster care grant and loss of support on its own was sufficient ground not to deduct the one from the other. Furthermore, the collateral source rule operates from the premise where the benefit is received by the plaintiff, and not by a third party for the benefit of the plaintiff. Therefore, an application of the Social Assistance Act and its regulations alone would have led to the conclusion that a foster care grant is predicated on the children's needs - however payable to the foster parent for the benefit of the children. This is certainly beyond the reach of the collateral source rule.

On the whole, the present author agrees with the Constitutional Court that the state, in providing the foster parents with a foster care grant, was discharging its constitutional obligations to the children. The present author further agrees that the multi-dimensional nature of fostering makes it inappropriate to deduct a foster care grant from a claim for loss of support.

\section{Social grants - A Third Collateral Benefit}

The Constitutional Court held that:

The purpose of the RAF is to give the greatest possible protection to claimants. A deduction of either foster child or child support grants would undermine that purpose. A reading of the RAF Act suggests that those grants should not be deductible. The RAF Act expressly provides that double compensation for persons who are entitled to claim under the Compensation for Occupational Injuries and Diseases Act [130 of 1993] should be deducted from compensation by the RAF but there is no equivalent reference to social grants (par 59).

Although the Constitutional Court did not expressly pronounce to this effect, the inference is that the court has extended the established list of res inter alios acta to include social grants. Thus, as of the date of judgment, general collaterals are (a) benefits received under ordinary contracts of insurance for which premiums are paid; (b) benefits received as solatium or from the generosity of third parties; and (c) social grants paid in terms of the Social Assistance Act.

\section{Conclusion}

It is submitted that the conclusion of the Constitutional Court is persuasive, namely that these grants are paid in view of the state's constitutional obligations and that (generally) a damage-causing event is not a necessary prerequisite for their provision. The Social Assistance Act is determinative of these requirements and is silent on their deductibility or otherwise in damages awards. The receipt of social grants is designed to safeguard the social security of citizenry and ought not to be considered an advantage in quantifying compensation. However, this is just about the only positive result coming out of the three Coughlan cases. It must be noted that although the High Court correctly ruled that the grant was a res inter alios acta, it held itself persuaded by the judgment 
in Makhuvela. The premise of that conclusion was based on the superficial distinction between foster care and child support grants. The distinction is without substance and the court ought not to have slavishly bound itself to it. The Supreme Court Appeal, though correctly finding that the distinction, in principle, is only relevant for categorisation of the respective grants, missed an opportunity to correct its decision in Timis. Despite the obviously incorrect decision in the latter case, what was most disconcerting about that judgment appears from the following passage:

It is important to stress that this finding does not mean that there is any general principle precluding an award of damages for loss of support where dependants have had the benefit of social support (par 22).

Over and above the legacy of casuistry, the cases represent a missed opportunity to set sound principles regarding the application of the collateral source rule. The determination of the rule still turns on a process of demarcation.

PL MONYAMANE University of South Africa 